\title{
Schistosoma mansoni in Brazil in 2015: retrieval of deaths and characteristics of patients that evolved to death
}

\section{Esquistossomose mansoni no Brasil em 2015: recuperação de óbitos e características dos pacientes com evolução a óbito}

\author{
Helio Milani Pegadoํ. Gilmara Lima Nascimento ${ }^{1}$. Maria Regina Fernandes de Oliveiraํ. \\ 1 Universidade de Brasília (UnB), Brasília, Distrito Federal, Brasil.
}

\begin{abstract}
Introduction: Schistosomiasis is a disease endemic in Brazil. We analyzed the death records from the Brazilian Mortality Information System with the aim of retrieving deaths due to schistosomiasis and describing the patients that evolved to death in Brazil in the year of 2015. Methods: We evaluated the death certificates for retrieving basic causes due to schistosomiasis, estimated the mortality rate and described the sociodemographic characteristics of patients. Result: To retrieve the basic cause, we analyzed 150 death certificates and we found 39 (26\%). Of the 406 studied deaths, 111 (27.3\%) occurred in people aged between 60 and 69 and $101(24.9 \%)$ between 70 and 79. Regarding the educational level, $196(62.4 \%)$ had not concluded the elementary school and 85 (27.1\%) had never studied. As to race/skin color, 248 deaths $(65.1 \%)$ occurred in black or pardo. Pernambuco registered more deaths, with 119 (29.3\%). Alagoas was the state presenting the highest mortality rate, with 1.62/100,000 residents. As immediate causes of death, most of them, 118 (29.1\%), occurred by hypovolemic shock. Conclusions: Deaths were more frequent in older ages, consistent with the disease chronic evolution, in people with lower educational level, and in subjects that reported themselves as black or pardo.
\end{abstract}

Keywords: Schistosomiasis. Epidemiology. Mortality Registries. Mortality. Schistosoma mansoni.

\section{RESUMO}

Introdução: A esquistossomose é uma doença endêmica em estados e municípios brasileiros. Neste estudo, foram analisados os registros do Sistema de Informação de Mortalidade (SIM) com a finalidade de recuperar óbitos decorrentes de esquistossomose e descrever características dos pacientes que evoluíram a óbito no Brasil no ano de 2015. Métodos: Foi realizado um estudo epidemiológico descritivo com dados do SIM, estimado o coeficiente de mortalidade e descritas as características sociodemográficas. Resultado: Foram analisadas 150 declarações de óbito que continham a esquistossomose citada em qualquer linha do atestado e foram recuperadas 39 (26\%). Dos 406 óbitos estudados, 111 (27,3\%) ocorreram em pessoas com idades entre 60 e 69 anos e $101(24,9 \%)$ entre 70 e 79 anos. Quanto à escolaridade, $196(62,4 \%)$ tinham fundamental incompleto e $85(27,1 \%)$ nunca estudaram. Quanto à raça/cor, 248 óbitos $(65,1 \%)$ ocorreram em pretos e pardos. Pernambuco registrou mais óbitos, com 119 (29,3\%). O estado com maior coeficiente de mortalidade foi Alagoas com 1,62/100.000 habitantes. Como causas imediatas de óbito, 118 óbitos $(29,1 \%)$ ocorreram por choque hipovolêmico. Conclusões: Os óbitos foram mais frequentes em idades mais elevadas, coerente com a evolução crônica da doença, em pessoas com baixa escolaridade e em autorreferidos como pretos e pardos.

Palavras-chave: Esquistossomose. Epidemiologia. Registros de mortalidade. Mortalidade. Schistosoma Mansoni.

Corresponding author: Hélio Milani Pegado, SQS 112, Bloco B, Asa Sul, Brasília, Distrito Federal, Brasil. CEP: 70375-020. Phone: +55 61 99952-2626. E-mail: helio94@gmail.com

Conflict of interests: The authors have no conflicts of interest to declare.

Received: 04 Sep 2018; Revised: 08 Dec 2018; Accepted: 08 Dec 2018. 


\section{INTRODUCTION}

Schistosomiasis represents a group of infectious diseases that have different etiological agents and sites of clinical manifestations: gastrointestinal schistosomiasis caused by S. guineensis, S. intercalatum, S. mansoni, S. japonicum and S. mekongi; bladder and urogenital schistosomiasis caused by $S$. haematobium and cerebral schistosomiasis caused by $S$. japonicum. ${ }^{1}$ The intestinal schistosomiasis caused by Schistosoma mansoni is the schistosomiasis of epidemiological relevance in Brazil. ${ }^{2}$

Schistosomiases represent the second most prevalent tropical disease in the world. They are internationally considered neglected diseases related to poverty and contributors to the poverty-disease-impoverishment cycle, with great socioeconomic repercussion. ${ }^{2}$ According to the World Health Organization (WHO), around 240 million people are estimated to be infected in the world, 760 million people are at risk of infection, and 200 thousand deaths occur every year in SubSaharan Africa associated with severe consequences of the disease. ${ }^{3,4}$

The disease is endemic in 19 federated states from Brazil, comprising a large extension of the national territory; and the main disease focuses are in the States of Sergipe, Bahia, Alagoas, and Pernambucco. ${ }^{5}$ In States and cities where the disease is endemic, transmission is more seen in areas marked by poor conditions of basic sanitation.

If the initial infection is not treated, infected people may evolve to extremely severe clinical forms, and may evolve to death. ${ }^{6,7}$ The disease evolution depends on the human being reaction to the invasion, development and posture of the worms' eggs, with a variety of clinical forms. The chronical forms assume different classifications in the late phase, based on the most affected organ: a) hepatointestinal; b) hepatic, characterized by periportal fibrosis without splenomegaly and portal hypertension; c) hepatosplenic that follows with periportal fibrosis with splenomegaly; d) complicated forms, such as vascular pulmonary; pseudoneoplasm: lymphoproliferative disease; glomerulopathy; neurological; as well as other ectopic locations. ${ }^{8}$

Considering it is a disease that may be fatal and be responsible for deaths in Brazil, reviewing the certificates of death due to such disease is essential for higher epidemiological comprehension. The Death Certificate (DC) is the main source of mortality data. The death statement is the part in the DC that identifies the death causes and is divided into two parts. The first one corresponds to completion of death causes and the second part provides the causes that contributed to death. This first part has lines identified by letters a, b, c, and d, in which the last line is completed with the basic cause of death. The basic cause of death is the disease or affection that began the chain of pathological events that directly lead to death. ${ }^{9}$ One of the DC copies is received in the City Departments of Health and the DC are recorded in the Brazilian Mortality Information System (SIM), which was essential to unify the DC from all parts of Brazil. ${ }^{6}$
Although there is standardization in the fulfillment of the death certificate, there are still many errors in filling out the DC that allow some deaths to be registered with other International Classification of Diseases (ICDs). ${ }^{10}$

This study aimed to analyze data obtained in the SIM database ${ }^{11}$ about patients with schistosomiasis that died in 2015 in order to retrieve possible deaths, in which schistosomiasis was not mentioned as the basic cause of death. In addition, we described patients that evolved to death presenting the schistosomiasis as basic cause - by adding the retrieved deaths - through their sociodemographic characteristics. We also estimated the schistosomiasis mortality rate in the year of 2015 , thus contributing to the description and knowledge of the death data in such period.

\section{METHODS}

\section{Study type}

We performed a descriptive epidemiological study. Firstly, we evaluated the death certificates for retrieving possible deaths due to schistosomiasis; secondly, we estimated the mortality rate and described the sociodemographic characteristics of patients that evolved to death due to schistosomiasis.

\section{Population and period}

We studied data from all patients that died in 2015 in Brazil and that presented the following International Classification of Diseases (ICD): B65, B65.0, B65.1 and B65.2 in any part of the death statement. We collected data from the SIM database. ${ }^{11}$

\section{Data collection and processing}

The process of death collection was performed in the SIM. We used this system to collect data from all patients presenting the ICD of schistosomiasis in any line of their death certificates.

After the process of collecting the deaths, we chose patients with schistosomiasis that, according to the DC, died due to other basic causes rather than schistosomiasis, based on the mentioned ICD.

We obtained 164 lines from these patients in an Excel table. These lines corresponded to all the ICD that were completed in these patients' death certificates. These ICD were organized in lines following the order of DC completion from line "a" to line "e".

Every recorded ICD was typed in the PesqCID program (Research in ICD 10 - DATASUS, version 2.4) and transcribed in a Microsoft Excel ${ }^{\circledR}$ spreadsheet.

The Excel table was analyzed line by line after the ICD of the death certificate had been decoded. We developed a clinical causal relation between the completed ICD in lines from "a" to " $d$ " of the DC. By means of this analysis, we were able to 
identify the relations of clinical causalities and to identify the basic cause of death according to the sequence of completion of the death statement.

We used the PesqCID program - Research in ICD $10-$ DATASUS, Version 2.4, to decode the ICD. The Microsoft Excel $^{\circledR}$ software was used to organize and present data.

\section{Consulted bibliographies for analysis of the death basic causes}

We used the following textbooks as bibliographic sources to analyze the death cause: "Harrison's principles of internal medicine"12 and "Doenças infecciosas e parasitárias" 5. ed., ${ }^{13}$ besides scientific articles that are duly referenced. ${ }^{14-26}$

We analyzed the death certificate lines and their clinical correlation in order to identify if schistosomiasis would be the basic cause of death, based on the disease physiopathology.

The considered causes of death due to schistosomiasis were: cases of hematemesis, bleeding of the esophageal varices, hypovolemic shock by hematemesis, ${ }^{13}$ death due to liver failure, portal hypertension with portal vein thrombosis ${ }^{15,20}$ embolism, ${ }^{18,23-25}$ and sepsis. ${ }^{26}$

Although some articles show the relation between sepsis and schistosomiasis, such relation was considered only when the word schistosomiasis appeared in the first part of the death certificate indicating that schistosomiasis had been contributing to sepsis. Therefore, we removed cases of death by septic shock, in which the word schistosomiasis appeared only in the second part of the death certificate, because it could indicate that schistosomiasis is a contributing cause, but not the cause of sepsis-related immunodepression. ${ }^{14,16}$

Liver neoplasm was accepted as a schistosomiasis-related disease $^{14,19,21}$ in cases where a sequence of completion was described in a way that schistosomiasis had to be mentioned before the neoplasm, indicating that the neoplasm had possibly occurred due to schistosomiasis and there were no confusion factors, such as comorbidity with hepatitis B and C.

The exclusion criteria of death recollection were: presence of blanks in the lines of the death certificate, which made impossible to determine the death cause and the presence of comorbidity with other liver diseases, such as patients with hepatitis B or C that could provide bias to the study, considering these diseases evolve with the clinics similar to schistosomiasis and could worse their manifestations. We considered blanks in the completion when only one line of the death certificate was completed.

\section{Process of death description, sociodemographic characteristics, and mortality}

After retrieving all deaths that had the schistosomiasis as basic cause, deaths were grouped according to the immediate conditions of death. We grouped them into 15 groups: hypovolemic shock; sepsis and infection; respiratory failure; liver failure and cirrhosis; cardiovascular diseases; other shocks; hepatorenal syndrome; anemia; cerebrovascular diseases; acute and chronic kidney failure; liver cancer; pulmonary embolism; metabolic disorders; acid-base disorders; and ill-defined causes.

In addition, we also assessed the sociodemographic data from all the patients that had schistosomiasis as the basic cause mentioned in the SIM, which were added to those data retrieved after analysis, and the mortality rates were estimated per State.

We calculated absolute and relative frequencies for the categorical variables and the median of ages. Then, we performed hypotheses tests through the chi-square statistical test for comparison between the selected variables at a 5\% decision level. Data were analyzed in the Microsoft Excel ${ }^{\circledR}$ and SPSS ${ }^{\circledR}$ programs.

\section{Ethical aspects}

This study is part of the project "Esquistossomose mansoni no Brasil - qual é a carga da doença?" [Schistosoma mansoni in Brazil - what is the disease burden?], which was submitted to the Ethics Committee from the Medical School of University of Brasília, receiving approval (Protocol $N^{\circ}$. 1.046.955, from April 29, 2015).

\section{RESULTS}

\section{Death recollection}

The SIM database included 531 deaths. Of these, 367 deaths presented the schistosomiasis as basic cause of death, which were removed from this retrieval analysis of basic causes.

Of the 164 remaining statements, nine of them were removed (around 5.5\%) because they were incomplete, i.e. they had only one completed ICD, besides the schistosomiasis ICD, which did not make viable the creation of a causal association and death understanding. We also removed five deaths due to comorbidity with Hepatitis B or C, as previously explained. Finally, one hundred and fifty deaths were analyzed and thirty nine were retrieved (Figure 1).

Of the 150 analyzed deaths, we found a completion error in $10(6.67 \%)$ statements that presented the ICD R092 of cardiac arrest in line A and the ICD R688 in 12 deaths (8.00\%), also in line $\mathrm{A}$, which corresponds to the ICD of other signs and symptoms that correspond to ill-defined causes of deaths.

After the analyses of deaths, we retrieved 39 deaths, $26 \%$ of the 150 analyzed deaths. Most of the retrieved deaths were due to hematemesis and corresponded to 17 deaths $(43.60 \%$ of the retrieved deaths) followed by liver failure in eight deaths $(20.51 \%)$, and complications of liver neoplasm in four deaths (10.26\%). In addition, the following were also responsible for death: respiratory failure secondary to pulmonary hypertension in three deaths $(7.69 \%)$, and sepsis/infections also in three deaths $(7.69 \%)$; there was one death $(2.56 \%)$ due to each one of these four causes: embolism, portal hypertension, thrombocytopenia, and cardiogenic shock secondary to pulmonary hypertension. 
Figure 1. Flowchart of the retrieval process of schistosomiasis deaths. Brazil, 2015.

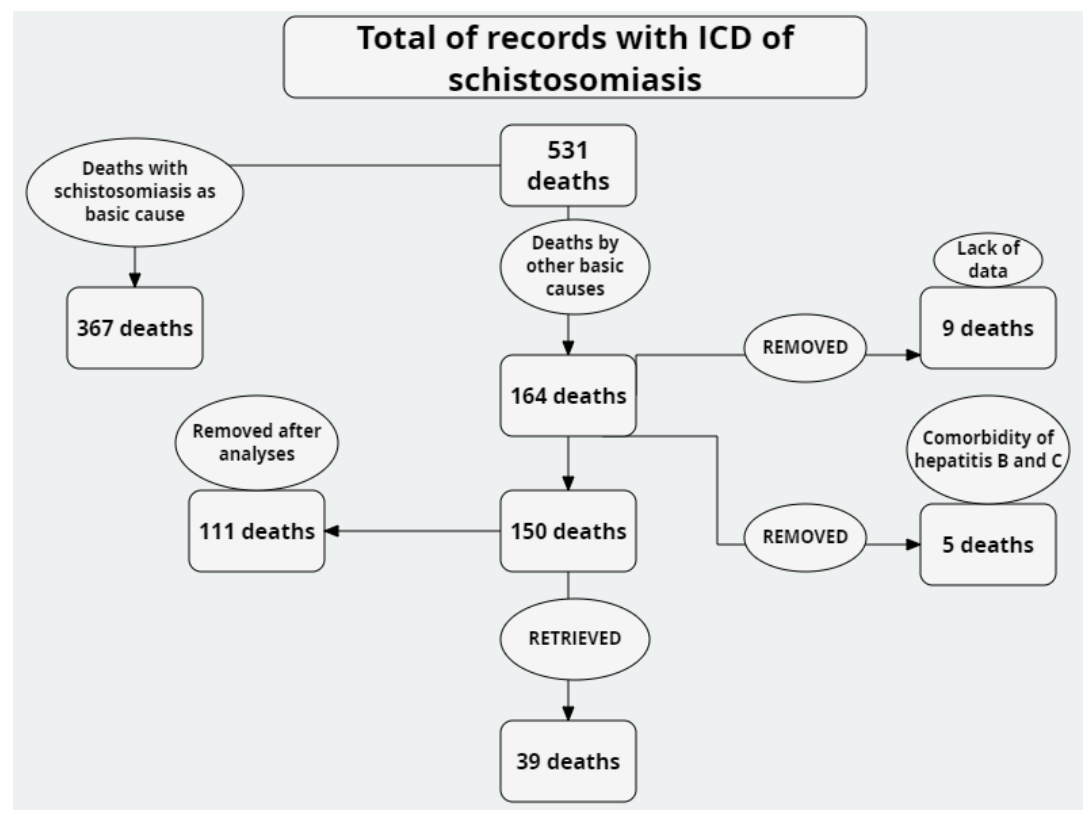

\section{Sociodemographic data}

We studied data from 406 patients that evolved to death by schistosomiasis, in which 367 deaths were already filled with the schistosomiasis mentioned as basic cause of death and 39 retrieved after analysis.

Of these patients, $206(50.74 \%)$ were men and $200(49.26 \%)$ were women (Table 1).

The median of ages was 66 years old (IIQ $57-76$ ). There were $111(27.34 \%)$ patients in the ages of $60-69$. The second age range with the highest number of deaths was 70-79, with 101 cases $(24.88 \%)$. There were only seven deaths between 0 and 29 years $(1.73 \%)$ (Table 1$)$.

The race/color was registered in 381 patients. Most of the schistosomiasis deaths occurred in people reported as black and pardo, corresponding to $248(65.09 \%)$ deaths, followed by white people with $129(33.86 \%)$. Of the registered patients, only four deaths occurred in indigenous people (around 1\%) (Table 1).

Regarding the educational level, there were 314 records in the SIM. Of these, 196 patients had not completed elementary school (62.42\%), 85 had never studied $(27.07 \%)$, and $6(1.91 \%)$ had completed or not completed upper school (Table 1).

The marital status was registered in 356 deaths. Of these, 166 (46.63\%) were married, $82(23.03 \%)$ were single, 66 (18.54\%) were widowed, $21(5.90 \%)$ were separated, and $11(3.09 \%)$ lived in consensual marriage.

We compared the proportions between the following variables: age range and immediate cause of death; gender and race; gender and age range; gender and immediate cause of death; and gender and educational level. We only found statistically significant results in the $5 \%$ decision level in the comparison between gender and educational level variables $(\mathrm{p}=0.002)$. Women presented lower educational level than men, except in the category of incomplete elementary school. It is noteworthy that the educational level presented $77 \%$ of completion in the database, but it did not have important differential losses for gender, with 158 men and 156 women under analysis (Table 2).

\section{Other results}

The majority of deaths, $343(84.48 \%)$, occurred in hospitals. The remaining, fifty of them $(12.32 \%)$, occurred at home and only thirteen deaths $(3.2 \%)$ occurred in other health units.

The Brazilian state with more records of deaths due to schistosomiasis was Pernambuco (119 deaths, 29.31\%), followed by Minas Gerais (70 deaths, 17.24\%), Bahia (54 deaths, 13.30\%), and São Paulo (52 deaths, 12.81\%) (Table 3). The Northeast Region had more records of deaths $(261,64 \%)$.

We calculated the gross mortality rate for each State and for Brazil. The mortality rate of Brazil was 0.20 per 100,000 residents. The state presenting the highest mortality rate was Alagoas with 1.62 per 100,000 residents, followed by Pernambuco with 1;27 per 100,000 residents, Sergipe with 0.67 per 100,000 residents, Bahia with 0.35 per 100,000 residents, and Minas Gerais with 0.33 per 100,000 residents (Table 3).

Of 406 patients, 259 deaths underwent necropsy. Of these, 36 $(13.9 \%)$ had the death diagnosis confirmed.

Among the immediate causes of death, the main one was hypovolemic shock in 118 deaths $(29.06 \%)$, followed by sepsis and infections in 76 deaths $(18.72 \%)$, respiratory failure in $54(13.30 \%)$, and liver failure and cirrhosis in 44 deaths (10.84\%). Thirty-eight records are highlighted (9.36\%) as illdefined causes of death (Table 4). 
Table 1. Distribution of schistosomiasis death cases according to gender, age, race/color, and educational level. Brazil, 2015.

\begin{tabular}{|c|c|c|}
\hline Variable & Number* & $\%$ \\
\hline \multicolumn{3}{|l|}{ Gender } \\
\hline Male & 206 & 50.74 \\
\hline Female & 200 & 49.26 \\
\hline Total & 406 & 100.00 \\
\hline \multicolumn{3}{|l|}{ Age range } \\
\hline 0 to 9 & 1 & 0.25 \\
\hline 10 to 19 & 2 & 0.49 \\
\hline 20 to 29 & 4 & 0.99 \\
\hline 30 to 39 & 16 & 3.94 \\
\hline 40 to 49 & 41 & 10.10 \\
\hline 50 to 59 & 63 & 15.52 \\
\hline 60 to 69 & 111 & 27.34 \\
\hline 70 to 79 & 101 & 24.88 \\
\hline 80 to 89 & 52 & 12.81 \\
\hline 90 to 99 & 15 & 3.69 \\
\hline Total & 406 & 100.00 \\
\hline \multicolumn{3}{|l|}{ Race/Color } \\
\hline Black and Pardo & 248 & 65.09 \\
\hline White & 129 & 33.86 \\
\hline Indigenous & 4 & 1.05 \\
\hline Total & 381 & 100.00 \\
\hline \multicolumn{3}{|l|}{ Educational level } \\
\hline Never studied & 85 & 27.07 \\
\hline Incomplete elementary school & 196 & 62.42 \\
\hline Incomplete high school & 27 & 8.60 \\
\hline Incomplete/complete upper school. & 6 & 1.91 \\
\hline Total & 314 & 100.00 \\
\hline
\end{tabular}

*White and ignored records were excluded.

Source: Adaptado de: Sistema de Informações sobre Mortalidade - SIM. ${ }^{11}$

Table 2. Distribution of schistosomiasis deaths cases according to gender and educational level. Brazil, 2015.

\begin{tabular}{|c|c|c|c|c|c|}
\hline \multirow{3}{*}{ Educational level } & \multicolumn{4}{|c|}{ Gender } & \multirow{3}{*}{ Total } \\
\hline & \multicolumn{2}{|c|}{ Male } & \multicolumn{2}{|c|}{ Female } & \\
\hline & $\mathbf{n}$ & $\%$ & $\mathbf{n}$ & $\%$ & \\
\hline Never studied & 34 & 21.52 & 51 & 32.69 & 85 \\
\hline Incomplete elementary school & 98 & 62.02 & 98 & 62.82 & 196 \\
\hline Incomplete high school & 21 & 13.91 & 6 & 3.85 & 27 \\
\hline $\begin{array}{l}\text { Complete/incomplete upper } \\
\text { school }\end{array}$ & 5 & 3.16 & 1 & 0.64 & 6 \\
\hline Total & 158 & 100.0 & 156 & 100.0 & $314 *$ \\
\hline
\end{tabular}

*White and ignored records were excluded. $(\mathrm{p}=0.002)$.

Source: Adaptado de: Sistema de Informações sobre Mortalidade - SIM. ${ }^{11}$ 
Table 3. Distribution of schistosomiasis death cases according to Federated States and mortality rate before and after the retrieve of deaths in Brazil. Brazil, 2015.

\begin{tabular}{lccccccc}
\hline \multicolumn{1}{c}{ Brazilian state } & Population & \multicolumn{3}{c}{ Before the retrieve } & \multicolumn{3}{c}{ After the retrieve } \\
& & $\mathbf{N}$ & $\mathbf{( \% )}$ & $\mathbf{M . R . *}$ & $\mathbf{N}$ & $\mathbf{( \% )}$ & M.R.* \\
\hline Alagoas & 3340932 & 49 & 13,35 & 1,47 & 54 & 13,30 & 1,62 \\
Pernambuco & 9345173 & 107 & 29,16 & 1,14 & 119 & 29,31 & 1,27 \\
Sergipe & 2242937 & 14 & 3,81 & 0,62 & 15 & 3,69 & 0,67 \\
Bahia & 15203934 & 50 & 13,62 & 0,33 & 54 & 13,30 & 0,35 \\
Minas Gerais & 20869101 & 64 & 17,43 & 0,31 & 70 & 17,24 & 0,33 \\
Paraíba & 3972202 & 9 & 2,45 & 0,27 & 9 & 2,22 & 0,23 \\
Espirito Santo & 3929911 & 7 & 1,9 & 0,18 & 8 & 1,97 & 0,2 \\
Distrito Federal & 2914830 & 3 & 0,81 & 0,1 & 4 & 0,99 & 0,14 \\
Rio Grande do Norte & 3442175 & 4 & 1,1 & 0,12 & 4 & 0,99 & 0,12 \\
São Paulo & 44396484 & 44 & 11,99 & 0,1 & 54 & 13,30 & 0,12 \\
Maranhão & 6904241 & 6 & 1,63 & 0,09 & 6 & 1,48 & 0,09 \\
Goiás & 6610681 & 5 & 1,36 & 0,08 & 5 & 1,23 & 0,08 \\
Rondônia & 1768204 & 1 & 0,27 & 0,06 & 1 & 0,25 & 0,06 \\
Rio de Janeiro & 16550024 & 3 & 0,82 & 0,02 & 4 & 0,99 & 0,02 \\
Paraná & 11163018 & 1 & 0,27 & 0,009 & 1 & 0,25 & 0,01 \\
\multicolumn{1}{c}{ Brazil } & $\mathbf{2 0 4 4 5 0 6 4 9}$ & $\mathbf{3 6 7}$ & $\mathbf{1 0 0}$ & $\mathbf{0 , 2}$ & $\mathbf{4 0 6}$ & $\mathbf{1 0 0}$ & $\mathbf{0 , 2}$ \\
\hline
\end{tabular}

*M.R. - Gross *Mortality Rate per 100 thousand residents.

Source: Adapted from: Sistema de Informações sobre Mortalidade - SIM. ${ }^{11}$; Instituto Brasileiro de Geografia e Estatística. ${ }^{27}$

Table 4. Distribution of schistosomiasis death cases according to immediate causes of death. Brazil, 2015.

\begin{tabular}{lcc}
\hline Immediate cause of death & Number of deaths & \% \\
\hline Hypovolemic shock & 118 & 29.06 \\
Sepsis and infection & 76 & 18.72 \\
Respiratory failure & 54 & 13.30 \\
Liver failure and cirrhosis & 44 & 10.84 \\
Ill-defined causes & 38 & 9.36 \\
Cardiovascular diseases and cardiogenic shock & 20 & 4.93 \\
Unspecified shock & 12 & 2.96 \\
Hepatorenal Syndrome & 9 & 2.22 \\
Anemia & 9 & 2.22 \\
Cerebrovascular diseases & 8 & 1.97 \\
Acute and chronic kidney failure & 6 & 1.48 \\
Liver cancer & 4 & 0.99 \\
Metabolic disorders & 4 & 0.99 \\
Pulmonary embolism & 3 & 0.74 \\
Acid-base disorders & 1 & 0.25 \\
Total & $\mathbf{4 0 6}$ & $\mathbf{1 0 0 \%}$ \\
\hline
\end{tabular}

Source: Adaptado de: Sistema de Informações sobre Mortalidade - SIM. ${ }^{11}$ 


\section{DISCUSSION}

We found inconsistencies in the completion of death certificates, such as the inversion between the causality sequence of the death certificate lines, which could damage the analysis of mortality and the accuracy of the basic causes of deaths by schistosomiasis based on SIM data as it was described for other diseases. ${ }^{10,28,29}$

In addition, we found $10 \mathrm{DC}$ that were incorrectly completed by the attribution of death to the cardiac arrest ICD. These DC completion errors may possibly occur due to the fast completion of the statements, lack of interest to fulfill them or even due to unawareness on how the DC completion should be done as described for Mendonça FM et al. ${ }^{28}$

We also observed that unspecific ICD were used to determine the death causes in the statements, such as R688 (of other signs and symptoms), which is in the group of ill-defined causes that difficulted the analyses and did not enable the recollection of some deaths. The use of these ICD that are not very specific like that of "other signs and symptoms" directly impacts the SIM, thus contributing to a system with lacks of accurate information regarding the death causes..$^{10,28,29}$

Among the retrieved deaths, most of them were caused by typical complications of schistosomiasis, such as hematemesis and liver failure. ${ }^{13,22}$ However, the relation between schistosomiasis and these complications may not have been established, due to unknowledge of the schistosomiasis physiopathology. Many doctors from non-endemic regions as São Paulo have to fill this DC.

The analyses described the sociodemographic aspects of 406 patients that died due to schistosomiasis in the SIM. In the studied records, death by schistosomiasis occurred both in men and in women, without gender distinction. Most of the patients evolved to death in the ages from 60-69 and 7079 , which shows that the disease may not be significantly decreasing the life expectancy. Nevertheless, even if it does not reduce the life expectancy in an impacting way, living with chronic schistosomiasis reduces the quality of life due to the severe events of repetition, multiple hospitalizations, and severity of clinical conditions.

We observed in the race/color distribution that the disease occurs more in black and pardo subjects, which is possibly

\section{REFERENCES}

1. Centers for Disease Control and Prevention (CDC). Parasites - Schistosomiasis [internet]. Atlanta: CDC; 2012 [acesso em: 23 fev 2018]. Disponível em: https://www.cdc.gov/parasites/ schistosomiasis/epi.html

2. Ministério da Saúde (MS). Vigilância da esquistossomose mansoni: diretrizes técnicas. 4. ed. Brasília: Ministério da Saúde; 2014.

3. World Health Organization (WHO). Informal consultation on expanding Schistosomiasis control in Africa. Geneva: WHO; 2010. associated with the worst socioeconomic conditions of this population in Brazil, favoring the disease cycle. The educational level that was more prevalent in the cases was incomplete elementary school, followed by patients that never studied. This variable is directly associated with lower socioeconomic conditions and worse housing and environment sanitation conditions. We highlight the significant difference in the educational level between men and women, which may show gender inequalities to the access to education in the populations affected by the disease, association also known in other studies as described for Gazzinelli A et al. ${ }^{30}$

Deaths occurred mostly in hospitals (84.48\%), followed by house and other health centers. Patients with schistosomiasis are severe patients with multiple complications that require great hospital support, who end up dying in this scenario.

São Paulo was the third region to register more deaths; even though is not endemic for the disease, probably it attracts many people with the disease that seek better medical-hospital support or more opportunity to work.

Necropsy does not seem very effective to confirm the postmortem diagnosis of schistosomiasis, considering that $86.1 \%$ did not have a confirmation of the schistosomiasis death, even after the procedure. It maybe occurred after the necropsy because there are some problems registering the DC after the necropsy as described by Stuque CO et al. ${ }^{29}$

The main causes of death in the total amount of deaths were hypovolemic shock caused by bleeding of the esophageal varices, followed by infections, respiratory failure or cirrhosis that are compatible with the disease systemic affection.

Finally, we need more awareness when completing the death certificate - a very important theme in the doctor's formation, because this is the only professional with legal competence to complete the DC. In addition, this paper showed a sociodemographic distribution that is compatible with the sickness-poverty cycle described in schistosomiasis and the severe morbidity associated with the disease. This shows the need of control measurements, especially in endemic areas like the State of Pernambuco, focusing on the population at socioeconomic vulnerability.

4. Vander Werf MJ, De Vlas SJ. Current estimated total number of individuals with morbidity and mortality due to Schistosomiasis Haematobium and S. Mansoni infection in Sub-Saharan Africa. Geneva: WHO; 2005 [acesso em: 23 jun 2018]. Disponível em: http://www.who.int/schistosomiasis/epidemiology/table/en/

5. Noya O, Katz N, Pointier JP, Theron A, Noya BA. Schistosomiasis in America. In: Franco-Paredes C, Santos-Preciato JI, editors. Neglected Tropical Diseases - Latin America and the Caribbean. Vienna: Springer; 2015. p. 11-43. 
6. Gryseels B, Polman K, Clerinx J, Kestens L. Human Schistosomiasis. Lancet. 2006;368:1106-18.

7. Rasia IC, Rosa AC, Rediss AN. A utilização dos sistemas de informação em uma instituição de saúde de Pelotas/RS. Rev Saúde. com. 2012;8(2):32-42.

8. Souza FP, Vitorino RR, Costa AP, Faria FC Júnior, Santana LA, Gomes AP. Esquistossomose mansônica: aspectos gerais, imunologia, patogênese e história natural. Rev Bras Clin Med. 2011;9(4):300-7.

9. Ministério da Saúde (MS). Fundação Nacional de Saúde. Manual de instruções para o preenchimento da declaração de óbito. 3. ed. Brasília: Ministério da Saúde; 2001. 42p.

10. Messias KL, Bispo-Junior JP, Pegado MF, Oliveira LC, Peixoto TG, Sales MA, et al. Qualidade da informação dos óbitos por causas externas em Fortaleza, Ceará, Brasil. Cien Saude Colet. 2016;21(4):1255-67.

11. Brasil. Ministério da Saúde (MS/SIM). Secretaria de Vigilância em Saúde. Sistema de Informações sobre Mortalidade - SIM [Internet]. Brasília: Ministério da saúde; 2015 [acesso em: 3 jun 2016]. Disponível em: http://tabnet.datasus.gov.br/cgi/deftohtm. exe?sim/cnv/pobt10uf.def.

12. Mahmoud AA. Schistosomiasis and other trematode infections. In: Longo DL, Fauci A, Kasper D, Hauser S, Jameson JL, Loscalzo J, editors. Harrison's principles of internal medicine. 18. ed. New York: McGraw-Hill; 2013. p. 1752-9.

13. Prata A. Esquistossomose mansoni. In: Veronese R, Focaccia R. Doenças infecciosas e parasitárias. 5. ed. Rio de Janeiro: Guanabara Koogan; 2015. p. 2015-38.

14. El-Tonsy MM, Hussein HM, Helal Tl-S, Tawfik RA, Koriem KM. Human Schistosomiasis mansoni associated with hepatocellular carcinoma in Egypt: current perspective. J Parasit Dis. 2016;40(3):976-80.

15. Leite LA, Pimenta AA Filho, Fonseca CS, Santos BS, Ferreira $\mathrm{RC}$, Montenegro SM, et al. Hemostatic dysfunction is increased in patients with hepatosplenic schistosomiasis mansoni and advanced periportal fibrosis. PLoS Negl Trop Dis. 2013;7(7):e2314.

16. Lima KM, Aires AL, Lucena LR, Almeida TM, Albuquerque $\mathrm{MC}$, Castro CM. [Factors influencing the bacterial translocation in mice with chronic schistosomiasis]. Acta Gastroenterol Latinoam. 2012;42(4):309-20. Spanish.

17. Olveda DU, Inobaya M, Olveda RM, Vinluan ML, Ng SK, Weerakoon $\mathrm{K}$, et al. Diagnosing schistosomiasis-induced liver morbidity: implications for global control. Int $\mathrm{J}$ Infect Dis. 2017;54:138-44.

18. Papamatheakis DG, Mocumbi AO, Kim NH, Mandel J. Schistosomiasis-associated pulmonary hypertension. Pulm Circ. 2014;4(4):596-611.
19. Sabry AH, El-Aal AA, Mahmoud NS, Nabil Y, Aziz IZ. An initial indication of predisposing risk of schistosoma mansoni infection for hepatocellular carcinoma. J Egypt Soc Parasitol. 2015;45(2):23340 .

20. Sinkala E, Kapulu MC, Besa E, Zyambo K, Chisoso NJ, Foster GR, et al. Hepatosplenic schistosomiasis is characterised by high blood markers of translocation, inflammation and fibrosis. Liver Int. 2016;36(1):145-50

21. Toda KS, Kikuchi L, Chagas AL, Tanigawa RY, ParanaguáVezozzo DC, Pfiffer T, et al. Hepatocellular carcinoma related to Schistosoma mansoni infection: case series and literature review. J Clin Transl Hepatol. 2015;3(4):260-4.

22. Barbosa CS, Souza Gomes EC, Campos JV, Oliveira FJ, Silva Mesquita MC, Oliveira EC, et al. Morbidity of Mansoni schistosomiasis in Pernambuco-Brazil: analysis on the temporal evolution of deaths, hospital admissions and severe clinical forms (1999-2014). Acta Trop. 2016;164:10-6.

23. Terra-Filho M, Mello MF, Lapa MS, Teixeira RH, Jatene FB. Clinical and haemodynamic evaluation of chronic thromboembolic pulmonary hypertension patients scheduled for pulmonary thromboendarterectomy: Is schistosomiasis hypertension an important confounding factor? Clinics. 2010;65(11):1155-60.

24. Abo-Salem ES, Ramadan MM. A huge thrombosed pulmonary artery aneurysm without pulmonary hypertension in a patient with hepatosplenic schistosomiasis. Am J Case Rep. 2015;16:140-5.

25. Fernandes CJ, Jardim CV, Hovnanian A, Hoette S, Morinaga LK, Souza R. Schistosomiasis and pulmonary hypertension. Expert Rev Respir Med. 2011;5(5):675-81.

26. Hübner MP, Layland LE, Hoerauf A. Helminths and their implication in sepsis - a new branch of their immunomodulatory behaviour? Pathog Dis. 2013;69(2):127-41.

27. Brasil. Instituto Brasileiro de Geografia e estatística. Estimativas da população residente no Brasil e unidades da federação com data de referência em $1^{\circ}$ de Julho de 2015 [Internet]; 2015 [acesso em: 4 jul 2017]. Disponível em: ftp://ftp.ibge.gov.br/Estimativas de Populacao/Estimativas_2015/estimativa_dou_2015_20150915. pdf

28. Mendonça FM, Drumond E, Cardoso AM. Problemas no preenchimento da declaração de óbito. R Bras Est Pop. 2010;27(2):285-95

29. Stuque CO, Cordeiro JA, Cury PM. Avaliação dos erros ou falhas de preenchimento dos atestados de óbito feitos pelos clínicos e pelos patologistas. J Bras Patol Med. Lab. 2003;39(4):361-4.

30. Gazzinelli A, Velasquez-Melendez G, Crawford SB, LoVerde PT, Correa-Oliveira R, Kloos H. Socioeconomic determinants of Schistosomiasis in a poor rural area in Brazil. Acta tropica. 2006;99(2-3):260-71.

\section{How to cite:}

Pegado HM, Nascimento GL, Oliveira MR. Schistosoma mansoni in Brazil in 2015: retrieval of deaths and characteristics of patients that evolved to death. Rev Med UFC. 2019 out-dez;59(4):14-21. 